\title{
Structural interpretation of High-resolution aeromagnetic data over the Dahomey basin, Nigeria: implications for hydrocarbon prospectivity
}

\author{
E. M Okoro ${ }^{1}$ (1) $\cdot$ K. M Onuoha ${ }^{1} \cdot$ C. G Okeugo ${ }^{1} \cdot$ C. I. P. Dim ${ }^{1}$
}

Received: 14 July 2020 / Accepted: 7 March 2021 / Published online: 22 March 2021

(c) The Author(s) 2021

\begin{abstract}
The renewed quest to boost Nigeria's dwindling reserves through aggressive search for oil and gas deposits in Cretaceous sedimentary basins has re-ignited the need to re-evaluate the hydrocarbon potentials of the Dahomey Basin. Aeromagnetic data are a low-cost geophysical tool deployed in mapping regional basement structures and determination of basement depths and sedimentary thickness in frontier basin exploration. In this study, high-resolution aeromagnetic (HRAM) data covering the Dahomey Basin Nigeria have been interpreted to map the basement structural configuration and to identify mini-basins favorable for hydrocarbon prospectivity. The total magnetic intensity grid was reduced to the equator (RTE) and edge detection filters including first vertical derivative (FVD), total horizontal derivative (THDR), tilt derivative (TDR) and total horizontal derivative of upward continuation (THDR_UC)) were applied to the RTE grid to locate the edges and contacts of geological structures in the basin. Depth to magnetic sources were estimated using the source parameter imaging (SPI) method. Data interpretation results revealed shallow and deep-seated linear features trending in the NNESSW, NE-SW, NW-SE and WNW-ESE directions. The SPI map showed a rugged basement topography which depicted a horst-graben architecture on 2D forward models along some selected profiles. Two mini-basins ranging in basement depths between $4.5-6.3 \mathrm{~km}$ were mapped offshore of the study area. It appears the offshore Dahomey Basin holds greater promises for hydrocarbon occurrence due to the presence of thicker succession of sedimentary deposits in the identified mini-basins.
\end{abstract}

Keywords Structures $\cdot$ HRAM Data $\cdot$ Hydrocarbon Prospectivity $\cdot$ Dahomey Basin

\section{Introduction}

The Dahomey Basin is located within the Gulf of Guinea, West Africa and covers the western coast of Nigeria on latitude $6^{\circ} 00^{\prime}-7^{\circ} 00^{\prime} \mathrm{N}$ and longitude $2^{\circ} 30^{\prime}-5^{\circ} 00^{\prime} \mathrm{E}$ (Fig. 1). The basin has become an important exploration target for the petroleum industry following the Federal Government's renewed quest to shore-up Nigeria's dwindling reserves through intensive search for conventional oil and gas deposits in frontier inland and coastal basins of Cretaceous age. This has resuscitated the need to critically interrogate the existing dataset in the Dahomey Basin and other

E. M Okoro

ezemartok@gmail.com

1 Department of Geology, University of Nigeria, Nsukka, Enugu State, Nigeria
Cretaceous sedimentary basins in the country including the Bida, Chad, Sokoto and Anambra Basins.

The Dahomey Basin developed as part of wrench tectonics associated with the Late Jurassic opening of the South Atlantic. Understanding the structural configuration of the basin in the context of the tectonic development of the Gulf of Guinea will be critical in providing insight into the controls on the distribution of mini-basins favorable for future hydrocarbon prospectivity in the basin. By mapping the structure and basement depth in the Dahomey Basin from the interpretation of high-resolution aeromagnetic data, the structural pattern will shed light on the prevalent tectonostress regimes responsible for the basin evolution and enable proper understanding of the dominant role the basement architecture played in the development of petroleum systems elements in the basin (Fairhead et al. 2012). Such regional geophysical study is needed to high-grade target areas within the basin for future concentration of exploration efforts. 


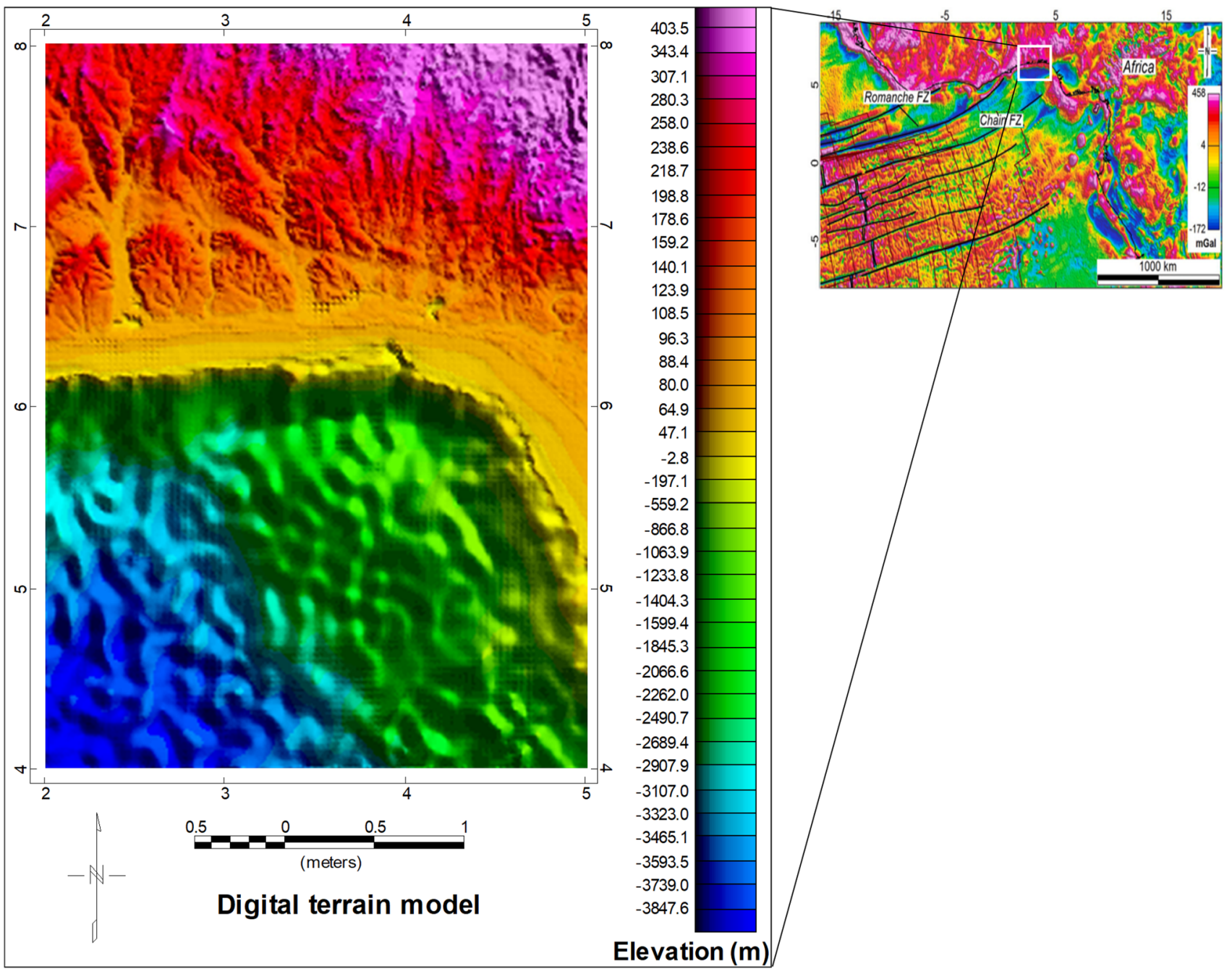

Fig. 1 Free-air gravity map of the Equatorial Atlantic Ocean ( modified from Tavares et al., 2020 and Sandwell et al., 2014 - version 28.1) showing location of the study area (white box) and Digital Terrain Model (Etopo1) of the Nigerian sector of the Dahomey Basin

Aeromagnetic measurements play a key role in the understanding of basement morphology and evolution of sedimentary basins. The aeromagnetic data are a proven cost-effective geophysical tool deployed in frontier basin exploration to map subsurface geological structures, infer the prevailing fault patterns and determine the depth to basement and sedimentary thickness ( $\mathrm{Li}$ and Morozov 2006; Saibi et al. 2016). Identification of faults and other linear features in the Dahomey Basin is critical to hydrocarbon exploration. Aeromagnetic data can provide valuable information on the location of faults in the basement. The basement structures may propagate into the overlying sediments where they affect subsurface fluid flow and hydrocarbon trap styles. Most oil and gas fields are associated with fault-dependent traps (Lyatsky et al. 2005; Ali et al. 2013; Mousa and Al-Rahim 2016). Sedimentary basins are often associated with low magnetic responses due to the presence of low magnetic susceptibility sediments in them. Hence, mapping the sediment-basement interface provides enhanced images of the basement geometry and variations in the sediment thicknesses (Oladele et al. 2016). In this study, high-resolution aeromagnetic data are interpreted to identify linear structures that may represent basement faults in the Dahomey Basin.

Structural characterization of the Dahomey Basin has been attempted by many researchers using different geophysical methods. Regional study by Oladele et al. (2016) utilized geopotential field attributes to infer the structural disposition of the Nigerian sector of the Benin Basin and showed that the basement structures play major role in controlling the trap styles and hydrocarbon migration in the basin. Oladele and Ayolabi (2014) used geopotential data to evaluate the hydrocarbon prospectivity of the Benin Basin Nigeria. They assigned a horst-graben architecture for the 
underlying basement, with the grabens accommodating over $6 \mathrm{~km}$ thick sediments. Using aeromagnetic and landsat data, Opara et al. (2012) investigated the structural characteristics of parts of the Benin Basin and identified linear structures and meso-fracture zone with major trends in the N-S and NE-SW directions.

Our study is focused on detailed structural interpretation of high-resolution aeromagnetic data to provide additional insights on the basement block pattern, basin architecture and determine how the basement structure have affected the distribution of mini-basins and petroleum systems development in the study area.

\section{Geological setting of the study area}

The Dahomey Basin extends from Volta-delta in Ghana on the West, to the southwestern part of Nigeria on the East where it terminates on the Okitipupa Ridge which separates it from the Tertiary Niger Delta Basin. Limits of the basin are defined by the Romanche (Ghana Ridge) and Chain (Okitipupa Ridge) Fractures Zone (Fig. 2). Evolution of the
Dahomey Basin and Gulf of Guinea are related to the tectonic development of the West and Central African Rift System (WCARS) which have been linked to the opening-up of the South Atlantic as Africa separated from South America in the Late Jurassic (Omatsola and Adegoke 1981; Onuoha and Ofoegbu 1988; Burke et al. 2003; Brownfield and Charpentier 2006; Kaki et al. 2013). Transcurrent motions along the Romanche, Chain and Charcot Fracture Zones initiated during the Early to Late Cretaceous rifting episodes controlled the formation of marginal basins along the West African Margin (Mascle et al. 1988). These marginal basins are dominated by high-angle normal faults bounding a series of linked half-grabens and rotated (tilted) fault blocks (Omatsola and Adegoke 1981). The major structures appear to have formed in the Neocomian to Barremian. The Late Cretaceous to Tertiary extensional and transtensional movements (drift stage) witnessed basin thermal sagging and deposition of continental clastics (Akande et al. 2012). Horizontal motions along oceanic transform systems translated into vertical displacements of the normal faults, resulting in block rotation and formation of horsts and graben structures (Omatsola and Adegoke 1981) which controlled

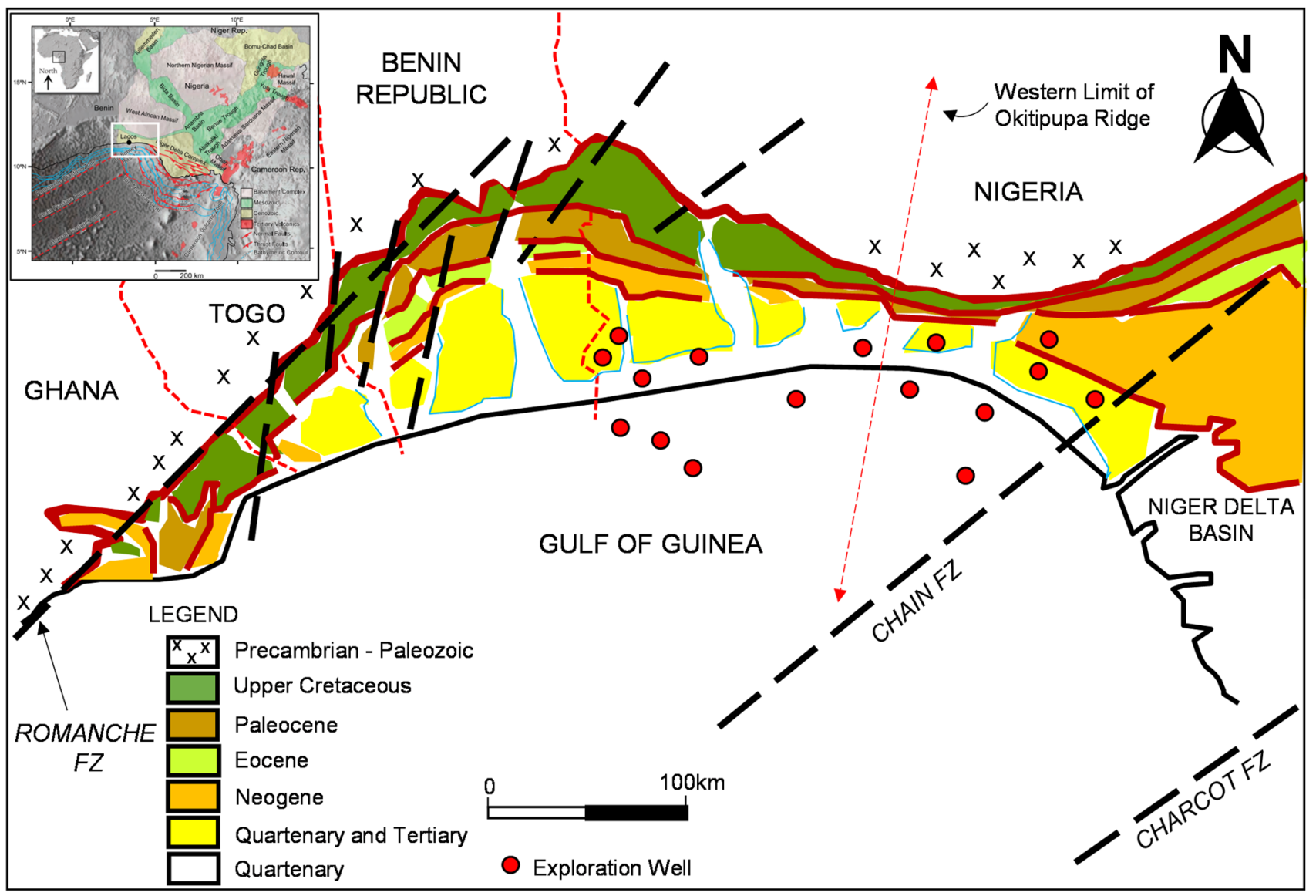

Fig. 2 Geological Framework of the Dahomey Basin (Modified after Billman, 1992) 
the deposition of Cretaceous to Tertiary sediments in the basin (Adeoye et al. 2013; Adekeye et al. 2019).

The stratigraphic sequence of the Dahomey Basin span from Cretaceous to Recent and detailed descriptions have been given in scholarly articles (e.g., Omatsola and Adegoke 1981; Billman 1992; Akande et al. 2012; Adeoye et al. 2013; d'Almeida et al. 2016; Adekeye et al. 2019). The geological formations reported in the basin include the Cretaceous Abeokuta Group which comprises of Ise, Afowo and Araromi Formations; the Paleocene Ewekoro Formation; the Late Paleocene to early Eocene Akinbo Formation; the Eocene Oshosun and Ilaro Formations and the Pleistocene to Recent Benin Formation (Fig. 3).

\section{Materials and methods}

\section{Aeromagnetic survey}

The study area was surveyed by the Nigerian Geological Survey Agency (NGSA) between December 2006 and May 2007. Data acquisition was conducted by Fugro Airborne Survey, using high sensitivity (0.001nT) 3 x Scintrex CS3 Cesium Vapor Magnetometers. The flight lines of the survey were flown at $80 \mathrm{~m}$ terrain clearance along equally spaced $(500 \mathrm{~m})$ parallel traverse lines in a NW-SE direction, with an azimuth of $135^{\circ}$, while the tie line was flown at right angles to the main flight line direction with an azimuth of $45^{\circ}$ from the true north.

The geomagnetic gradient was removed from the data using the International Geomagnetic Reference Field (IGRF) formula for 2005, and other pre-processing operations such as micro-levelling, deculturing, removal of effects from metallic features, etc., were performed on the

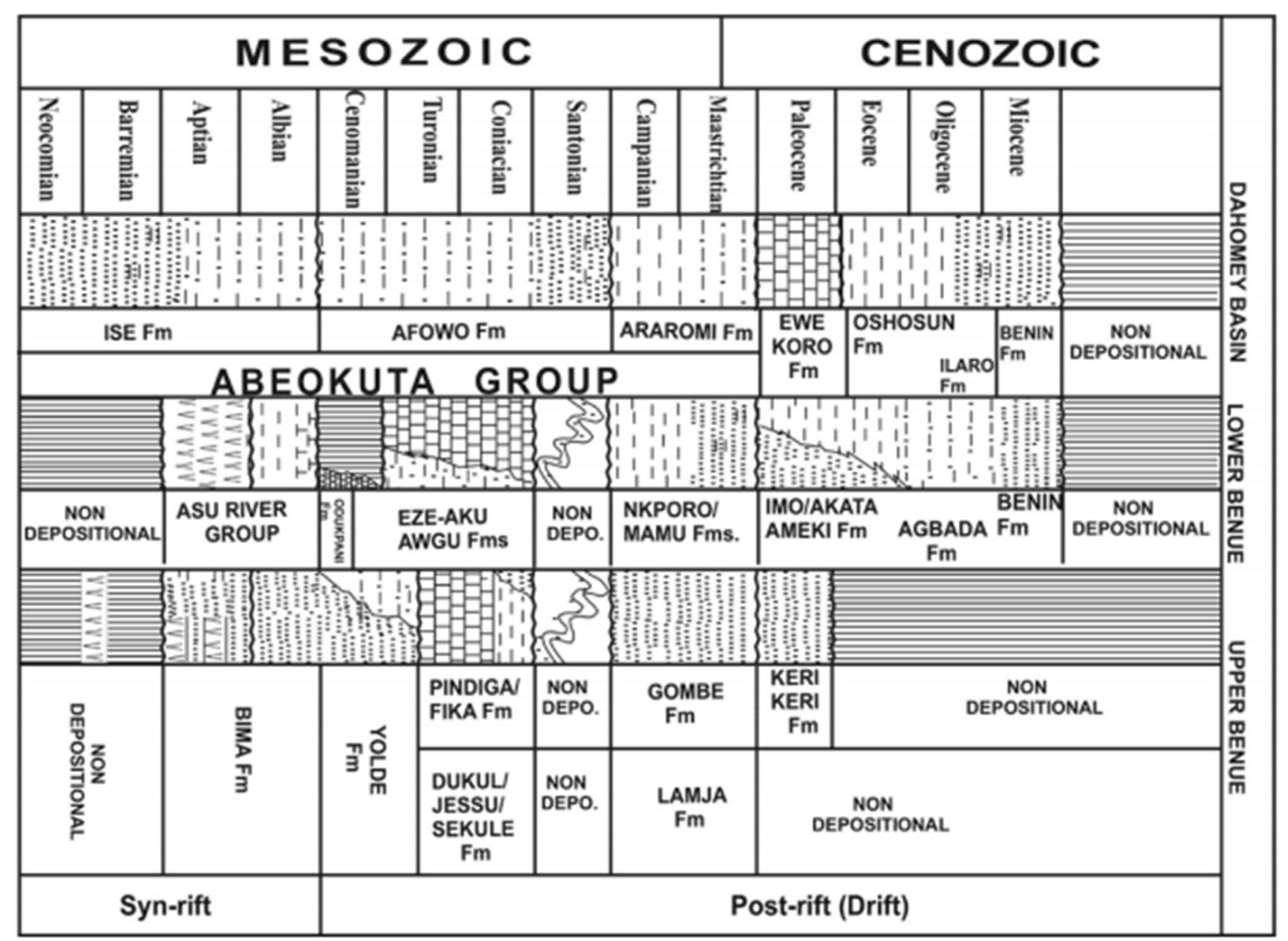

Fig. 3 Generalized Stratigraphic Chart of the Eastern Dahomey Basin and the Benue Trough (After Akande et al., 2018)

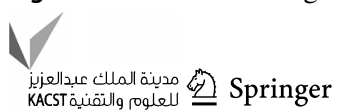


newly acquired data. The data were then interpolated into rectangular grids of $125 \mathrm{~m}$ cell size (equivalent to a quarter of the flight line spacing) using a minimum curvature algorithm to produce the total magnetic intensity (TMI) grid. Each TMI grid is presented on a scale of 1:100000 and half degree sheet, covering an area of about $55 \times 55$ $\mathrm{km}^{2}$. Ten aeromagnetic data grids (sheets: $278,279,280$, $281,282,278 \mathrm{~A}, 279 \mathrm{~A}, 280 \mathrm{~A}, 281 \mathrm{~A}$ and 296) covering the study area were obtained from NGSA and merged into a single TMI grid. The white portions on the TMI map represent missing data sections where no data were acquired. The TMI data formed the basis for further application of enhancement filters needed for detailed structural interpretation of the study area.

\section{Data analysis and interpretation techniques}

The TMI data were reduced to the magnetic equator (RTE) in order to remove the asymmetry in magnetic anomalies at low latitudes and ensure that the anomalies are symmetrically centered over their causative sources. Structural enhancement filters were then applied to the RTE grid to locate the edges and contacts of linear features. The edge detection methods used in this study include first vertical derivative (FVD), total horizontal derivative (THDR), tilt derivative (TDR) and total horizontal derivative of upward continuation $(10 \mathrm{~km})$. Lineaments extracted from these maps were analyzed using rose diagrams to infer the dominant tectonic trends in the study area.

Depths to magnetic sources were determined using the source parameter imaging (SPI) method, while 2D forward modeling of selected profiles was performed with the GMSYS $^{\mathrm{TM}}$ module of Oasis Montaj software to establish the basement block pattern and architecture.

The routines adopted in this study have been given in classical literatures (e.g., Whitehead and Musselman 2008; Nabighian et al. 2005; Reeves 2005; Thurston et al. 2002; Roest et al. 1992; Thompson 1982). However, they are briefly highlighted from the next paragraph.

First Vertical Derivative (FVD). The first vertical derivative calculates the rate of change of magnetic signal in the vertical direction. The filter enhances short wavelength effects associated with shallow features. Mathematically, the first vertical derivative is given by the equation

$F V D=-\frac{\partial F}{\partial Z}$

This edge detection filter is good for delineating near surface contacts and lineaments.

Total Horizontal Derivative (THDR). The THDR is defined as
$T D H R=\sqrt{\left(\frac{\partial M}{\partial x}\right)^{2}+\left(\frac{\partial M}{\partial y}\right)^{2}}$

where $(\partial \mathrm{M} / \partial \mathrm{x})$ and $(\partial \mathrm{M} / \partial \mathrm{y})$ are the horizontal derivatives of the magnetic field. Generally, the total horizontal derivative anomaly generated by a tabular body tends to overlie the edges of the anomalous body, whether vertical or horizontal and separated from each other (Cordell and Grauch 1985). Because it has low sensitivity to noise in the data, the THDR filter is a good detector of shallow linear structures since it only requires computation of the first horizontal derivatives of the field in $\mathrm{x}$ and $\mathrm{y}$ directions (Cooper and Cowan 2008). The THDR maxima was used in this study to delineate edges of near-surface features such as faults and fracture networks.

Tilt Derivative (TDR). The tilt derivative (Verduzco et al. 2004) filter is defined by the arctangent of the ratio of the vertical derivative of the potential field to its total horizontal derivative

$T D R=\tan ^{-1}\left(\frac{V D R}{T H D R}\right)$

This technique is a powerful method for detecting the edges of source bodies and for mapping shallow basement structures (Ibraheem et al. 2018). The range of variation of the tilt derivative amplitude is between $-\pi / 2$ and $\pi / 2$; positive values are located over the sources, zero values at/near the source edge and negative values are located away from the source (Verduzco et al. 2004). Enhancement filters that boost subtle (short wavelength) anomalies also exacerbate the short wavelength noise, which needs to be suppressed before applying the filter (Lyatsky et al. 2005). In this study, noise suppression was achieved by slightly upward continuing the RTE data by $1 \mathrm{~km}$ before computing the TDR grid.

Upward Continuation (UC). This mathematical technique enhances the effects of deep-seated (long wavelength) anomalies. It transforms the magnetic data by calculating the field at constant elevation (h) above the plane of measurement (Miranda and Introcaso 1999). The upward continuation filter smoothens the data by attenuating the noise, thereby removing the effects of shallow sources and emphasizing long wavelength anomalies associated with deep-seated regional features in the survey area. The upward continued $(\Delta \mathrm{F})$ of the total field anomaly at higher elevation $(\mathrm{z}=-\mathrm{h})$ is given by:

$\Delta F(x, y,-h)=\frac{h}{2 \pi} \iint \frac{\Delta F(x, y, 0) d x d y}{\left(\left(x-x^{0}\right)^{2}+\left(y-y^{0}\right)^{2}+h^{2}\right)}$

Equation (4) gives the field at an elevation (h) above the plane of the observed field $(\mathrm{z}=0)$ in terms of the average value $\Delta \mathrm{F}$ at the point $(\mathrm{x}, \mathrm{y}, \mathrm{o})$.

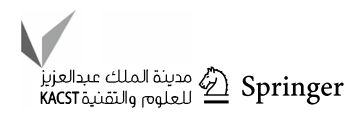


The RTE grid was upward continued to $10 \mathrm{~km}$ above the survey plane to suppress the near-surface effects and enhance long wavelength anomalies. Total horizontal derivative (THDR) of the upward continued grid was then computed in order to enhance the edges of deep-seated regional features in the study area.

Source Parameter Imaging (SPI). The SPI method (Thurston et al. 2002; Thurston and Smith 1997) is based on the principle of complex analytic signal which computes source parameters from gridded magnetic data. The basics is that for vertical contacts, the peaks of the local wavenumber define the inverse of depth. Hence, the depth is calculated using the formula:

Depth $=\frac{1}{K_{\max }}$

where $\mathrm{K}_{\max }$ is the peak value of the local wavenumber $\mathrm{K}$ over the steep source. The wave number is given by the expression:

$K_{\max }=\sqrt{\left(\frac{\partial T i l t}{\partial x}\right)^{2}+\left(\frac{\partial T i l t}{\partial y}\right)^{2}}$

and Tilt is expressed as arctan (VDR/HGRAD), i.e.,

$\arctan \left[\frac{\partial T / \partial z}{\sqrt{\left[(\partial T / \partial x)^{2}+(\partial T / \partial y)^{2}\right]}}\right]$
SPI solution grids show the susceptibility contrasts, depths, edge locations and dips of magnetic source bodies. Therefore, SPI map more closely resembles the geology, giving better image of the basement-sediment interface than either the original magnetic data or its derivatives. The SPI method was used in this study to determine the depth to anomalous causative bodies and to map the basement topography.

\section{Results and discussion}

\section{Magnetic expressions of the study area}

The reduced to the equator magnetic intensity (Fig. 4) map shows alternations in strong and weak magnetic anomalies reflecting variations in the magnetization of underlying basement rocks in the study area. The anomalies were interpreted as high (red), low (blue) and intermediate (yellow to green), with dominant trends in the NE-SW, NW-SE, N-S, WNW-ESE and E-W directions, respectively. High magnetic anomalies ranging from $49.4-103.7 n T$ were observed at the central portion and parts of the eastern portion of the RTE map; while low anomalies between -4.1 and $-66.2 n T$ dominate the southern, southwestern and parts of the northeastern portions. The southeastern and parts of the northeastern and central portions of the study area are dominated by intermediate anomalies ranging from $4.6-47.4 \mathrm{nT}$. The observed magnetic expressions in the study area generally reflect strong anomalous features of different amplitudes and sizes that trends nearly parallel to the basin configuration.

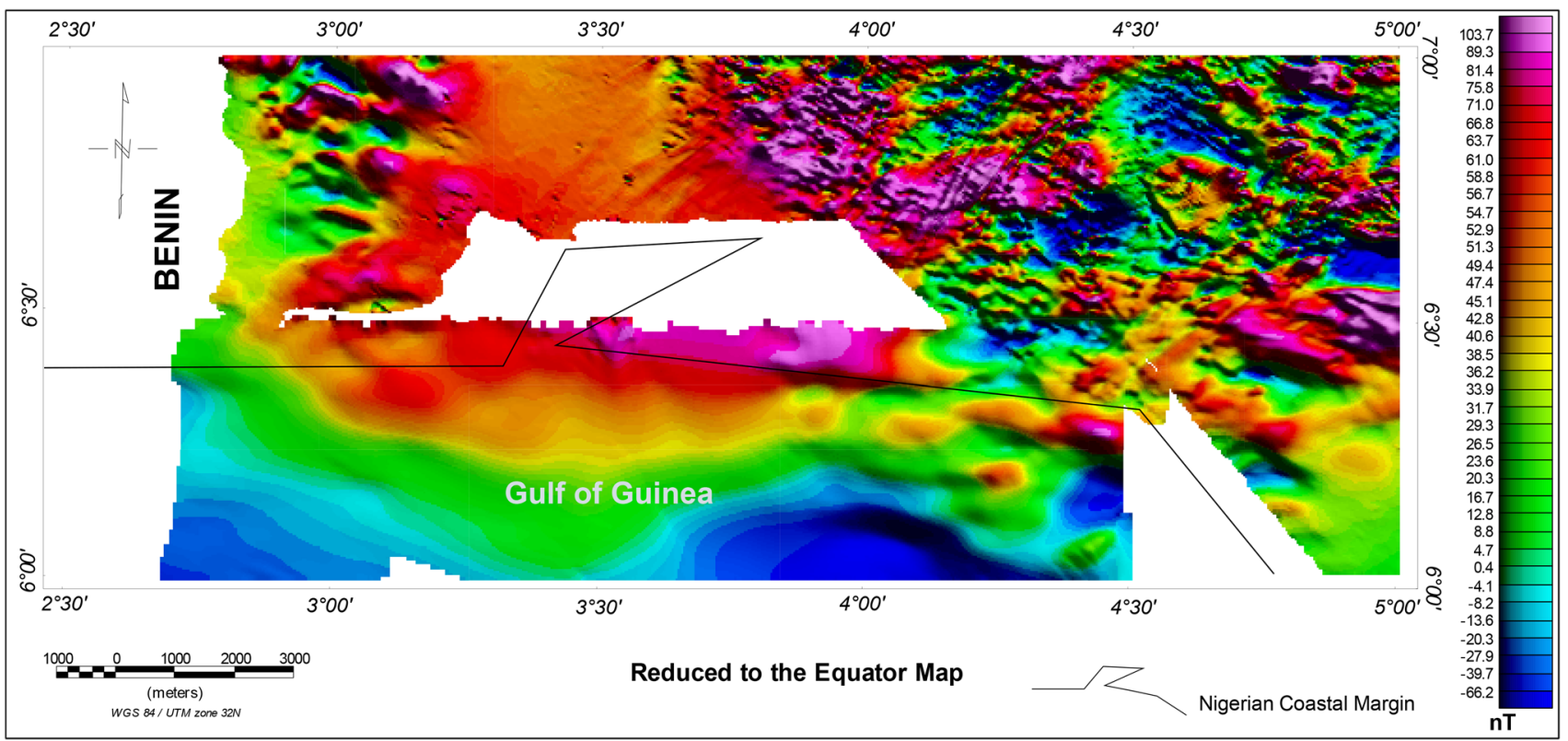

Fig. 4 Reduced to the Equator Magnetic Intensity Map of the study area 
The anomalies exhibit sharp magnetic boundaries, suggesting effects from vertical or steeply dipping contacts.

\section{Structural features of the dahomey basin}

\section{Shallow structures}

Shallow structures inferred from the FVD (Fig. 5), THDR (Fig. 6) and TDR (Fig. 7) maps include lineaments (faults and fractures systems) with different orientations in the

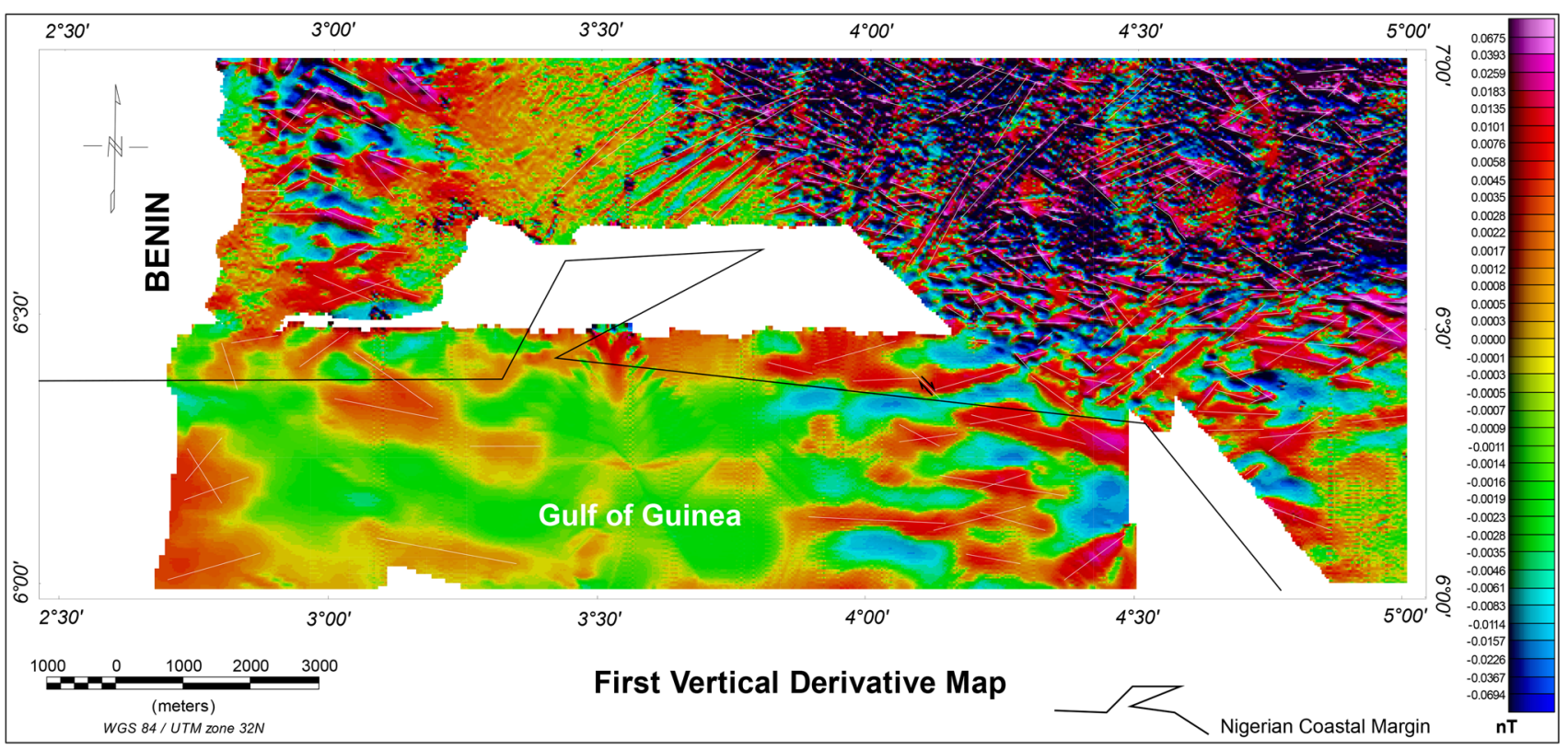

Fig. 5 First vertical derivative map showing the shallow faults and lineaments in the study area
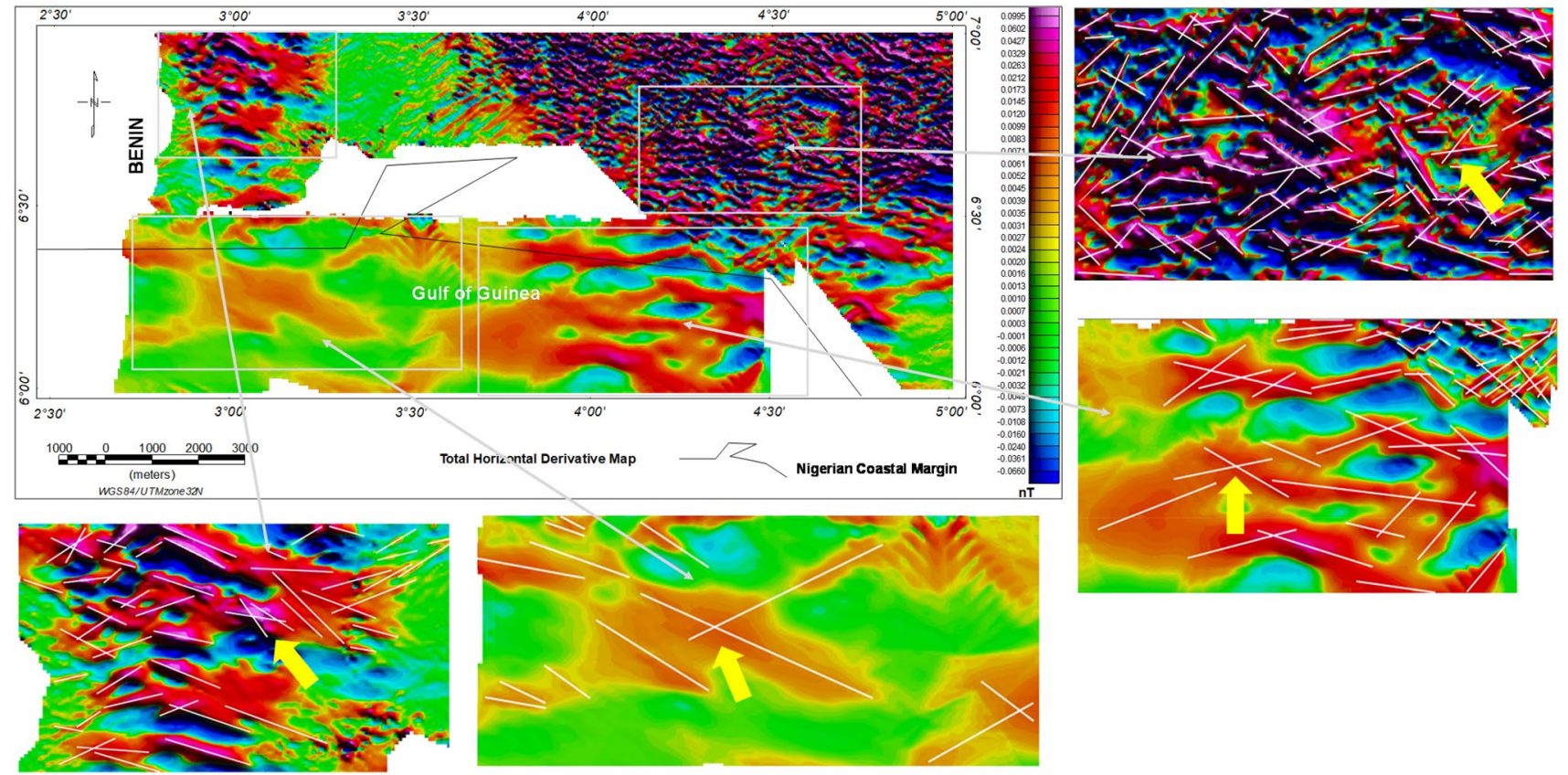

Fig. 6 Total horizontal derivative map showing the observed conjugate systems both onshore and offshore of the study area. Yellow arrow shows the cross-cutting relationships of the mapped linear features 


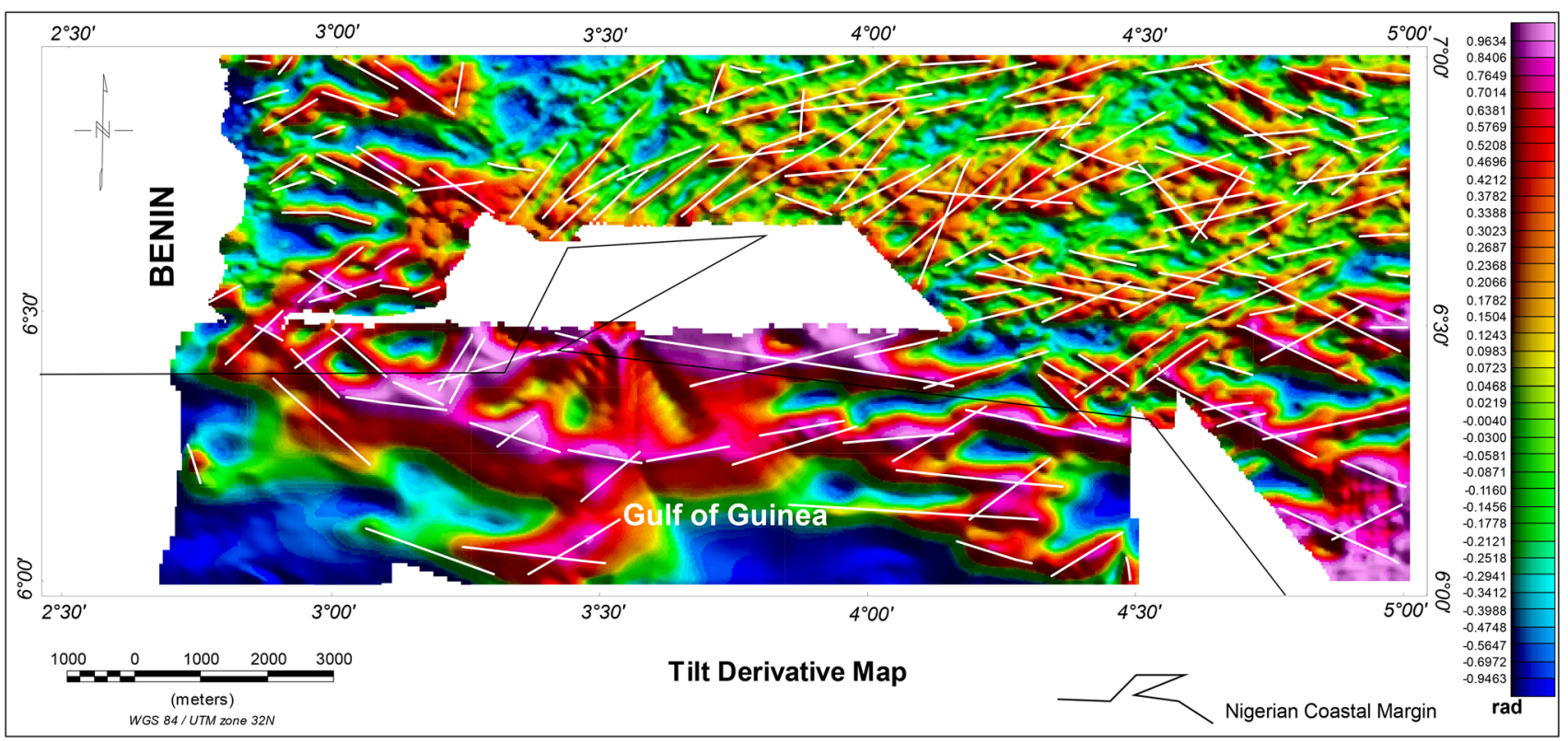

Fig. 7 Tilt derivative map showing the delineated subtle faults and lineaments in the study area

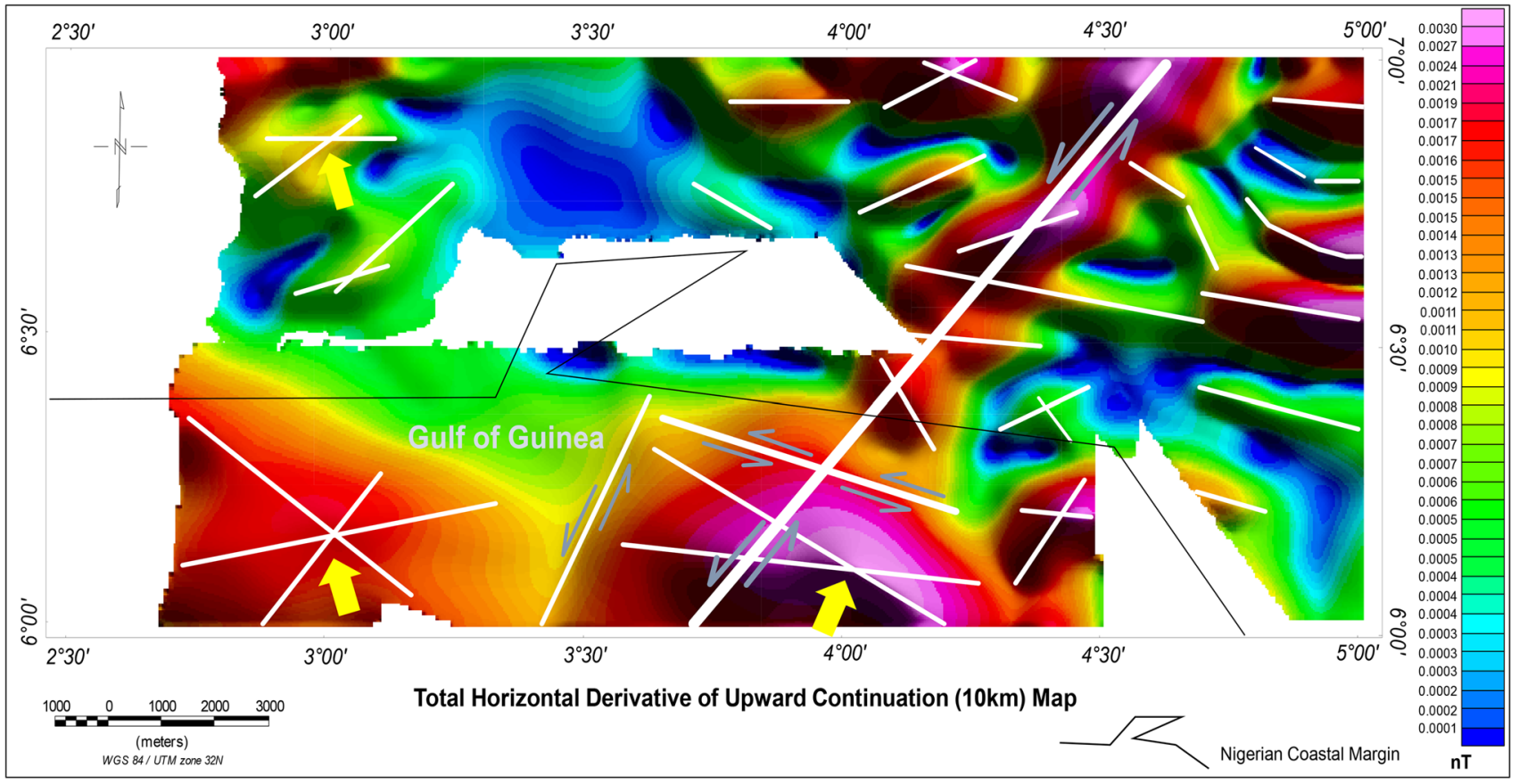

Fig. 8 Total horizontal derivative of Upward Continuation $(10 \mathrm{~km})$ map showing the delineated Deep-seated linear structures. The structures exhibit a conjugate nature as pointed by the yellow arrows

NW-SE, NE-SW, NNE-SSW and WNW-ESE directions. The FVD and TDR maps showed similarity in locating the edges of linear features and for detecting the edges of shallow basement contacts in the study area. The TDR map better resolved subtle anomalies not clearly imaged on the FVD and THDR maps. The fault systems gave clue to their tectono-genesis. The NE-SW and NNE-SSW trending faults have been characterized to be the basement bounding faults because of their similarity to the oceanic transform systems that extended into the basin from the Atlantic Ocean (Kaki et al. 2013; Oladele et al. 2016). As 
the basin evolved through different tectonic episodes, the NW-SE and WNW-ESE trending faults were formed.

\section{Deep-seated structures}

Deep-seated basement structures identified on the total horizontal derivative of upward continuation $(10 \mathrm{~km})$ map showed strong trend in the NNE-SSW direction, with a minor NW-SE trend (Fig. 8). The structures were interpreted to be deep-seated ancient zones of crustal weakness that controlled the structural development of the basin during the Early Cretaceous break-up of the Gondwana Supercontinent (Oluyide 1988; Onuoha and Ofoegbu 1988). The lineaments cut across each other, typical of conjugate systems associated with wrench tectonics, suggesting that they are products of transtensional forces associated with the Early Cretaceous rifting responsible for the basin formation (Mascle and Blarez 1987; Nemčok et al. 2012; Davison et al. 2015; Mustapha et al. 2019). The wrench-related movements along oceanic fracture zones which could be traced into the Gulf of Guinea (Guiraud et al. 1992; Fairhead et al. 2013) were evident on the aeromagnetic map. One major
NE-SW trending anomaly was clearly traced into the Atlantic Ocean. This anomaly possibly represents the continental manifestation of the Chain Fracture Zone (i.e., western limit of Okitipupa Ridge) which marks the eastern boundary of the Dahomey Basin (Billman 1992; Oladele et al. 2016). According to Eze et al. (2011), the overprinting relationship between the conjugate wrench systems indicates that the NW-SE trending lineaments are younger in age than the NNE-SSW lineaments.

\section{Lineament trends and their tectonic significance}

Rosette diagram plots of the lineaments interpreted from the filtered aeromagnetic maps were used to determine the dominant structural trends in the basin. The observed trends gave insights on the tectonic origin of the structures and were directly linked to the processes responsible for the evolution of marginal basins within the Gulf of Guinea (Guiraud et al. 1992; Mustapha et al. 2019). Four lineament sets trending in the NE-SW, NNE-SSW, NW-SE and WNW-ESE directions were identified in the study area (Fig. 9). The shallow and deep-seated structures cut across each other, representing
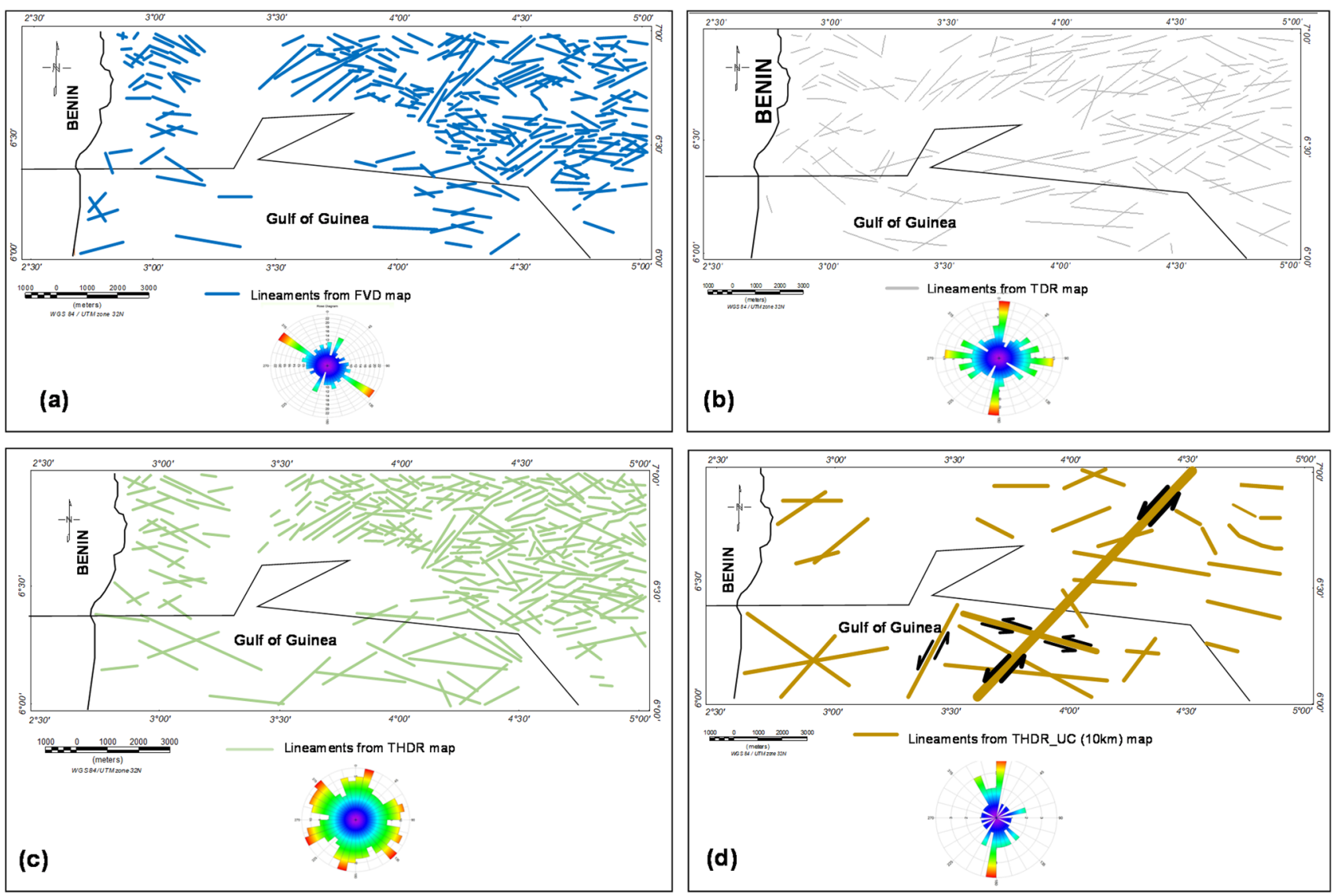

Fig. 9 (a-d). Lineaments interpreted from FVD, TDR, THDR and THDR_UC (10km) maps. The rosette diagrams show the major structural trends of the linear features 


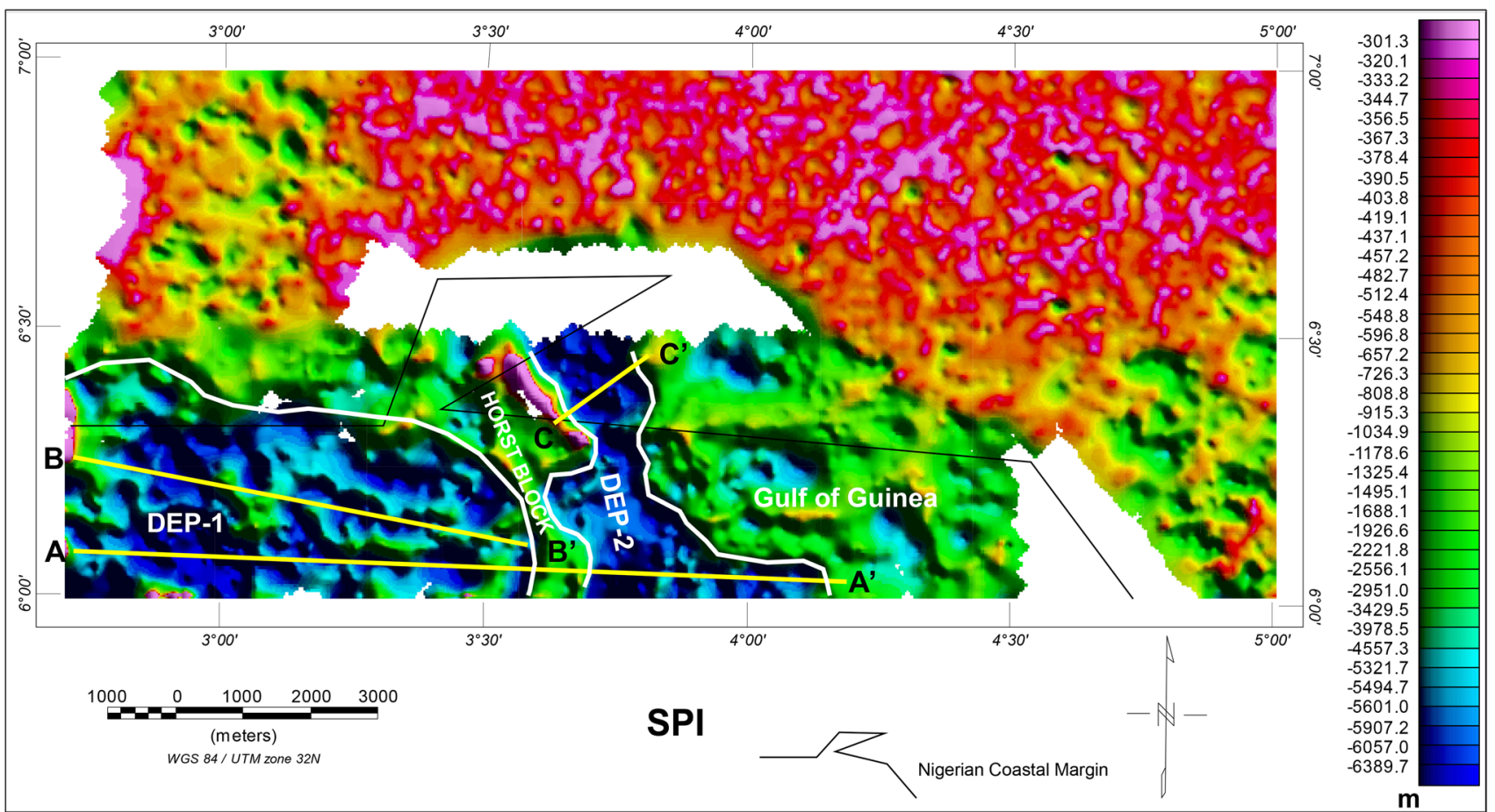

Fig. 10 SPI depth to basement map showing the mapped mini-basins (Graben-1 and Graben-2). Lines A - A', B - B' and C - C' in yellow are modeled profiles across the mini-basins (Fig. 11)

conjugate systems associated with wrench tectonics. This suggests that the faults and fractures are products of extensional, transtensional and transpressional movements along oceanic fracture zones as African and South American Plates separated (Fairhead et al. 2013; Gaina et al. 2013). Aeromagnetic interpretation revealed that the lineaments are extensional features corresponding to normal faults, most of which were reactivated into strike-slip shear fractures during the evolutionary stages of the basin. The NE-SW and NNESSW lineaments represent transtensional features, with the NE-SW system being the oldest in the basin (Oluyide 1988; Oladele et al. 2016).

The NW-SE lineaments form conjugate shear fractures that postdates the NE-SW lineaments. Also, the NW-SE systems predates another set of conjugate shear fracture oriented in the WNW-ESE direction. Tectonic evolution of all these lineaments is attributed to the Late Jurassic separation of Africa from South America and the plate tectonic interaction (far-field stress) between Africa and Euro-Asian Plates (Fairhead et al. 2012). Hence, the observed lineament trends in the study area are interpreted to be products of the basement re-organizations resulting from different tensional and compressional episodes responsible for the basin development (Semere and Woldai 2006; Fairhead et al. 2013).

The NNE-SSW and NE-SW trends are contemporaneous with the Early Cretaceous extensional and transtensional forces that acted on oceanic fracture zones and produced deep half-graben structures along the West African Margin (Davison et al. 2015). Transtensional faults in the Gulf of Guinea vary in orientation from NNE to E direction and were controlled both by the pre-existing Pan-African basement weaknesses and the principal stresses. Zones of weakness in the Precambrian basement are generally orientated NE-SW in the adjacent onshore areas, while E- to ENEorientated strike-slip faults have also been mapped in West African Margin (Nemčok et al. 2012; Davison et al. 2015).

The NW-SE and WNW-ESE lineament trends are attributed to basement re-adjustments to the Late AlbianCenomanian and the Santonian compressional events in the Gulf of Guinea (Benkhelil et al. 1998). They may have also resulted from the far-field stresses emanating from the African-Euro-Asian Plates interactions which are transmitted into the Dahomey Basin via the West and Central African Rift System chain (Teasdale 2001; Eze et al. 2011; Fairhead et al. 2012).

\section{Magnetic basement depth and sedimentary thickness}

Determination of basement depth using the source parameter imaging (SPI) method revealed variations in the depth to different anomalous sources and sedimentary thickness across the basin. The SPI depth map clearly imaged the rugose basement topography of the study area. The estimated depth 
values varied between $0.3-6.3 \mathrm{~km}$ from onshore to offshore. Major basement depressions (mini-basins) mapped offshore of the study area attained depths ranging between 4.5-6.3km. The two mini-basins were designated as "Dep1" and "Dep-2" (Fig. 10). They are located in the western and central parts of the offshore Dahomey Basin and are separated by a horst block. The basements uplifts largely control the trapping mechanism in the study area since they may influence the formation of anticlinal closures and faultdependent traps. The estimated depth to basement in the identified mini-basins represents the sedimentary thickness in the study area. The depth values obtained in this study agree fairly with earlier findings in the basin (e.g., Opara et al. 2012; Kaki et al. 2013; Oladele and Ayolabi 2014; Oladele et al. 2016).

The mini-basins are characterized by the presence of smaller grabens and horsts within grabens and they become progressively deeper into the ocean basin, with regional tilt toward the southeast. The geometry of these Dep-2 structure suggests that it may have been responsible for the creation of deep sea channels (e.g., the Avon Canyon) through which turbidite deposits were transported into the ocean basin. This basement depression may have also controlled the development of the present-day Lagos Lagoon. In general, most parts of the mini-basins have not been penetrated by the drill bit. The offshore Dahomey Basin therefore holds greater prospects for finding new conventional hydrocarbon deposits to add to Nigeria's depleting reserves. Hence, future exploration campaigns should target the offshore Dahomey Basin to test the potentials of the Lower Cretaceous sequences in the mini-basins.

\section{D Forward modeling and basement block pattern}

2D forward modeling of some selected profiles across the mini-basins gave insights on the basement block pattern (Fig. 11). This was combined with geologic interpretation of the observed aeromagnetic signatures to deduce the overall basement architecture in the study area. In the 2D models, the syn-rift sediments were assigned a magnetic susceptibility value of $0.035 \mathrm{SI}$, while the post-rift sediments were assigned 0.030SI magnetic susceptibility. Different magnetic expressions of the basement were accounted for by varying the basement depth within the range of $0.5-6.5 \mathrm{~km}$, using magnetic susceptibility of 0.050 SI. The rugose basement relief showed two major depressions separated by a horst block depicting a horst and graben architecture. The grabens attained sedimentary thickness ranging from $4.5 \mathrm{~km}$ to more than $6 \mathrm{~km}$, suggesting that they are high hydrocarbon prospective zones.

The alternation of high and low aeromagnetic signatures observed on the RTE map suggested basement high (horst) and low (graben). High magnetic anomalies also suggest regions with high magnetite content such crystalline basement rocks, while regions with low magnetic anomaly show areas with relatively low magnetite content. These variations reflect the block pattern and rugose morphology of the underlying basement rocks. The interpreted high and low magnetic responses indicate high susceptibility basement uplift and low susceptibility sediment-filled depression, thus imposing a horst-graben architecture on the underlying basement rocks in the basin.

The 2D models revealed that the basement morphology was influenced by such processes as block faulting, tilting and rotation. Hence, the block pattern largely controlled the basement relief, which in turn affected the near-surface structures and possibly the overlaying stratigraphy. Thus, the basement architecture has a direct link to the basin's tectono-stratigraphic history and may have also controlled the distribution of petroleum systems and play elements, as well as trap styles in the basin. The horst blocks will enhance the formation of anticlinal and fault-dependent traps, while the source facies, reservoirs and seals are deposited in the grabens. Sedimentary facies variations will result in stratigraphic traps, while the faults will act as hydrocarbon migration pathways.

\section{Conclusion}

Detailed analysis and interpretation of high-resolution aeromagnetic data covering the Dahomey Basin, Nigeria have been attempted in this study. Robust application of geopotential field methods in delineating subsurface structures, basement architecture and sediment thickness variations has also been demonstrated. Magnetic signatures of the study area showed alternations in high and low anomalies, indicating variations in magnetic susceptibility of the underlying basement and sedimentary rocks. Interpretation of shallow and deep-seated structures revealed the presence of wrenchrelated faults and fracture systems, with major trends in the NNE-SSW, NE-SW, NW-SE and WNW-ESE directions. These geological features gave clue to the different tectonic regimes that have affected the basin through time.

Sedimentary thickness varied across the basin from onshore to offshore, with estimated depths to basement from SPI map ranging from $0.3-6.3 \mathrm{~km}$. Two major basement depressions (Dep-1 and Dep-2) located in the offshore areas attained depths ranging from $4.5 \mathrm{~km}$ to $6.3 \mathrm{~km}$. The mini-basins are adjudged to be highly prospective zones for hydrocarbon occurrence due to the accumulation of considerably thick sediments in them.

From the 2D forward models, it was observed that the sediment-basement interface has a rugged topography. The basement block pattern was largely affected by block faulting, tilting and block rotation, leading to a horst-graben

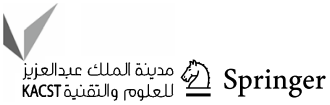



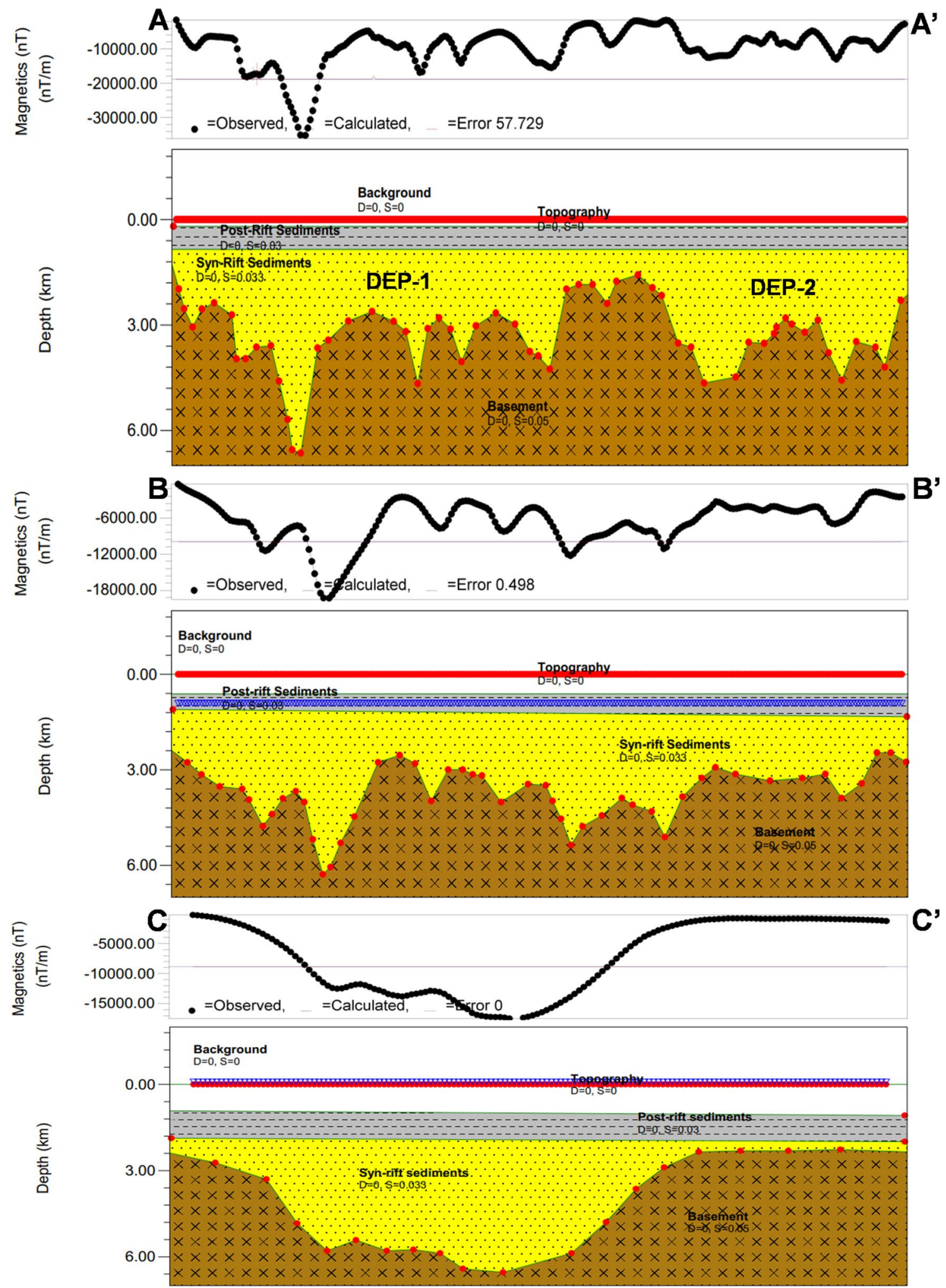

Fig. 11 Profiles A-A', B - B' and C-C's showing the block pattern and horst-graben architecture of the basement in the study area 
architecture, which has a common relationship with the tectonic and stratigraphic development of the basin, as well as the distribution of hydrocarbon systems. It therefore appears that the offshore Dahomey Basin holds significant promises for finding new conventional oil and gas deposits to boost Nigeria's dwindling reserves. It will make more sense to have future exploration efforts focused in this area for improved hydrocarbon prospectivity.

Acknowledgements Our sincere appreciation goes to the Petroleum Technology Development Fund (PTDF) for sponsorship. We are also grateful to the Nigerian Geological Survey Agency (NGSA) for releasing the aeromagnetic dataset used in this study. We thank the anonymous reviewer and the Chief Editor for their insightful suggestions which has greatly improved the quality of the manuscript.

Funding There are no funding statement for this journal. However, the first author is a recipient of the Petroleum Technology Development Fund (PTDF) local scholarship award for postgraduate students in Nigeria. Hence, PTDF was acknowledged in this paper.

Open Access This article is licensed under a Creative Commons Attribution 4.0 International License, which permits use, sharing, adaptation, distribution and reproduction in any medium or format, as long as you give appropriate credit to the original author(s) and the source, provide a link to the Creative Commons licence, and indicate if changes were made. The images or other third party material in this article are included in the article's Creative Commons licence, unless indicated otherwise in a credit line to the material. If material is not included in the article's Creative Commons licence and your intended use is not permitted by statutory regulation or exceeds the permitted use, you will need to obtain permission directly from the copyright holder. To view a copy of this licence, visit http://creativecommons.org/licenses/by/4.0/.

\section{References}

Adekeye OA, Akande SO, Adeoye JA (2019) The assessment of potential source rocks of Maastrichtian Araromi formation in Araromi and Gbekebo wells Dahomey Basin, southwestern Nigeria. Heliyon 5(5):e01561. https://doi.org/10.1016/j.heliyon.2019.e01561

Adeoye JA, Akande SO, Adekeye OA (2013) The Cenomanian-Turonian successions in the Benue Trough and Dahomey Basin, Nigeria: petroleum potential evaluation from new source rock data. In: NAPE proceedings of the 30th annual international conference and exhibition, November 11-15, vol 2012. pp 90-93

Akande SO, Adekeye OA, Adeoye JA, Jacob N, Lufadeju G (2012) Paleoecologic and organic geochemical assessment of cretaceous hydrocarbon source rocks in the gulf of Guinea: new insights from eastern Dahomey and Benue rift basins with implications for the Cenomanian-Coniacian petroleum system. In: Extended Abstract, AAPG Annual Convention and Exhibition, Long Beach, California, pp $1-10$

Akande SO, Adekeye OA, Adeoye JA, Ojo OJ, Adeoye MO, Dominic W, Erdtmann BD (2018) Burial and thermal history of cretaceous sediments in the Dahomey, Anambra and Gongola rift basins: implications for coal facies distribution and petroleum potential. FUOYE J Pure Appl Sci 3(1):308-325

Ali MY, Watts AB, Farid A (2013) Gravity anomalies of the United Arab Emirates: implications for basement structures and infraCambrian salt distribution. GeoArabia 18(4):49-80
Benkhelil J, Mascle J, Guiraud M (1998) Sedimentary and Structural Characteristics of the Cretaceous Along the Côte D'Ivoire-Ghana Transform Margin and In the Benue Trough: A Comparison ${ }^{1}$. In: Mascle J, Lohmann GP, Moullade, M (Eds.), 1998 Proceedings of the Ocean Drilling Program, Scientific Results, 159:93-99

Billman HG (1992) Offshore stratigraphy and paleontology of Dahomey (Benin) Embayment. NAPE Bull 70(02):121-130

Brownfield ME, Charpentier RR (2006) Geology and total petroleum systems of the gulf of guinea province of West Africa. USGS Bulletin, $2207-\mathrm{C}: 32$

Burke K, MaCgregor DS, Cameron NR (2003) In Arthur TJ, MaCgregor DSN, Cameron NR (Edition), petroleum geology of Africa: new themes and developing technologies. Geol Soc, London, Special Publ 207:21-60

Cooper GRJ, Cowan DR (2008) Edge enhancement of potential-field data using normalized statistics. Geophysics 73(3):H1-H4

Cordell L, Grauch VJS (1985) Mapping basement magnetization zones from aeromagnetic data in the San Juan basin, New Mexico. In the Utility of Regional Gravity and MagneticAnomaly Maps; Hinzc WJ Ed. Society of Exploration Geophysicists:181-197

d'Almeida GAF, Kaki C, Adeoye JA (2016) Benin and Western Nigeria offshore basins: a stratigraphic nomenclature comparison. Int J Geosci 7:177-188

Dailly P, Henderson T, Kanschat K, Lowry P, Sills S (2017) The Jubilee Field, Ghana Opening the Late Cretaceous Play in the West African Transform Margin In Merrill RK, Sternbach CA eds Giant Fields of the Decade 2000-2010. AAPG Memoir 113: 257-272

Davison I, Faull T, Greenhalgh J, Beirne EO, Ian S (2015) Transpressional structures and hydrocarbon potential along the Romanche Fracture Zone: a review. In Nemčok, et al. (eds)-Transform Margins: Development, Controls and Petroleum Systems. Geological Society, London, Special Publications 431:1-14

Eze CL, Sunday VN, Ugwu SA, Uko ED, Ngah SA (2011) Mechanical Model for Nigerian Intraplate Earth Tremors. earthzine.org, $1-6$

Fairhead JD, Mazur S, Green CM, Yousif ME (2012) Regional tectonic controls on basement architecture and oil accumulation within the Muglad basin, Sudan. $22^{\text {nd }}$ International Geophysical Conference and Exhibition, Brisbane, Australia 1-5

Fairhead JD, Green CM, Masterton SM, Guiraud R (2013) The role that plate tectonics, inferred stress changes and stratigraphic unconformities have on the evolution of the Westand Central African rift system and theAtlantic continental margins. Tectonophysics 594:118-127

Gaina C, Trond HT, van Hinsbergen DJJ, Sergei M, Werner SC, Labails C (2013) The African plate: a history of oceanic crust accretion and subduction since the Jurassic. Tectonophysics 604:4-25

Guiraud R, Binks RM, Fairhead JD, Wilson M (1992) Chronology and geodynamic setting of Cretaceous-Cenozoic rifting in West and Central Africa, Tectonophysic, Elservier Science Publishers B.V. Amsterdam 213:227-234

Ibraheem IM, Elawadi EA, El-Qady GM (2018) Structural interpretation of aeromagneticdata for the Wadi El Natrun area, northwestern desert. Egypt J Afr Earth Sci 139:14-25

Kaki C, d'Almeida GAF, Yalo N, Amelina S (2013) Geology and petroleum systems of the offshore benin basin oil and gas science and technology-rev. IFP Energies nouvelles 68(2):363-381

Ladipo KO, Lipede A (2019) The Frontier Inland Basins of Nigeria: Strategies to Realize the significant Undiscovered Potential. Extended abstracts, NAPE Special Workshop on Cretaceous Basins in Nigeria:22-27

Li J, Morozov IB (2006) Structural styles of the Precambrian basement underlying the Williston Basin and adjacent regions - an interpretation from geophysical mapping. In Summary of Investigations. Sask Geol Surv 1:1-18 
Lyatsky HV, Pana DI, Grobe M (2005) Basement structure in central and southern alberta: insights from gravity and magnetic maps. EUB/AGS Spec Rep 72:1-76

Mascle J, Blarez E (1987) Evidence for transform margin evolution from ivory coast-Ghana continental margin. Nature 326:378-381

Mascle J, Blarea E, Marinho M (1988) The shallow structures of the Guinea and ivory Coast-Ghana transform margins-their bearing on the equatorial atlantic mesozoic evolution. Tectonophysics 155:193-209

Miranda S, Introcaso A (1999) Cartas Gravimétricas de la Provincia de Córdoba. Interpretación de la estructura profunda de la Sierra de Córdoba. República Argentina. UNR Editora. Temas de Geociencia N 1, (Rosario) (in Spanish): 45

Mousa A, Al-Rahim A (2016) Lineaments determination of western part of Iraqi western desert using aeromagnetic and gravity data. Int J Eng Res Sci 2(12):79-92

Mustapha M, Amponsah P, Bernard P, Bekoa A (2019) Active Transform Faults in the Gulf of Guinea: Insights from geophysical data and implications for seismic hazard assessment. Canadian Journal of Earth Sciences:1-39

Nabighian MN, Grauch VJS, Hansen RO, LaFehr TR, Li Y, Peirce JW, Philips JD, Ruder ME (2005) The historical development of the magnetic method in exploration. Geophysics 70:33-61

Nemčok M, Henk A, Allen R, Sikora PJ, Stuart C (2012) Continental break-up along strike slip fault zones; observations from equatorial Atlantic. In: Mohriak WU, Danforth A, Post PJ, Brown DE, Tari GM, Nemčok M, Sinha ST (eds) Conjugate Divergent Margins. Geological Society, London, Special Publications 369:537-556

Okoro EM, Onuoha KM (2019) Structural Styles and Basement Architecture of the Dahomey Basin from Geophysical Data. Extended Abstracts, NAPE Special Workshop on Cretaceous Basins in Nigeria:110-114

Oladele S, Ayolabi EA (2014) Geopotential imaging of the benin basin for hydrocarbon prospectivity. NAPE Bull 26(1):101-112

Oladele S, Ayolabi EA, Dublin-Green CO (2016) Structural characterization of the nigerian sector of benin basin using Geopotential field attributes. J Afr Earth Sci, Elsevier 121:200-209

Oluyide PO (1988) Structural trends in the Nigerian basement complex. In: PO Oluyide, WC Mbonu, AE Ogezi, IG Egbuniwe, AC Ajibade, AC Umeji (Eds), Precambrian Geology of Nigeria, Geological Survey of Nigeria, Kaduna:93-98

Omatsola ME, Adegoke OS (1981) Tectonic Evolution and cretaceous stratigraphy of the dahomey basin. J Min Geol 8:30-137

Onuoha KM, Ofoegbu CO (1988) Subsidence and evolution of Nigeria's continental margin: implications of data from Afowo-1 well. Marine Petrol Geol 5:175-181
Opara AI, Ekwe AC, Okereke CN, Nosiri OP (2012) Integrating airborne magnetic and landsat data for geologic interpretation over part of the benin basin. Nigeria Pac J Sci Technol 13(1):556-571

Reeves CV (2005) Aeromagnetic Surveys, Principles, Practice and Interpretation; Geosoft: 155

Roest WR, Verhoef J, Pilkington M (1992) Magnetic interpretation using the 3D analytic signal. Geophysics 57:116-125

Saibi H, Azizi M, Mogren S (2016) Structural investigations of Afghanistan deduced from remote sensing and potential field data. Acta Geophys. https://doi.org/10.1515/acgeo-2016-0046

Sandwell DT, Müller RD, Smith WHF, Garcia E, Francis R (2014) New global marine gravity model from CryoSat 2 and Jason-1 reveals buried tectonic structure. Science 346(6205):65-67

Semere S, Woldai G (2006) Lineament characterization and their tectonic significance using Landsat TM data and field studies in the central highlands of Eritrea. J Afr Earth Sci, Elsevier 46:371-378

Tavares AC, de Castro DL, Bezerra FHR, Oliveira DC, Vannucchi P, Iacopini D, Jovane L, Vital H (2020) The Romanche fracture zone influences the segmentation of the equatorial margin of Brazil Journal of South American Earth Sciences 103 (2020) 102738:1-17

Teasdale J, Lynn P, Mike E, Stuart-Smith P, Loutit T, Zhiqun S, John V, Phil H (2001) Bass Basin Structurally Enhanced view of Economic Basement (SEEBASETM) Project:1-51

Thompson DT (1982) EULDPH - A new technique for making computer-assisted depth estimates from magnetic data; Geophysics:31-37

Thurston JB, Smith RS (1997) Automatic conversion of magnetic data to depth, dip, and susceptibility contrast using the SPI ${ }^{\mathrm{TM}}$ method: Geophysics 62:807-813

Thurston J, Smith RS, Guillion JC (2002) A multi model method for depth estimation from magnetic data. Geophysics 67:555-561

Verduzco B, Fairhead JD, Green CM, MacKenzie C (2004) New insights into magnetic derivatives for structural mapping. Lead. Edge 23:116-119

Whitehead N, Musselman C (2008) Montaj Grav/Mag Interpretation: Processing, Analysis and Visualization System for 3D Inversion of Potential Field Data for Oasis montaj v6.3, GeosoftIncorporated, 85 Richmond St. W.,Toronto, Ontario, M5H 2C9, Canada

Publisher's Note Springer Nature remains neutral with regard to jurisdictional claims in published maps and institutional affiliations. 